\title{
THE APPLICATION OF CONTINUOUS QUALITY IMPROVEMENT METHODS AT UNIVERSITIES IN THE OPINION OF STUDENTS AND LECTURERS OF THE UNIVERSITY OF LODZ
}

Elżbieta Zalewska, MSc.

\author{
University of Lodz \\ Faculty of Economics and Sociology \\ Department of Statistical Methods \\ Rewolucji 1905 r., 41, 90-214 Lodz, Poland \\ e-mail: elzbieta.zalewska@uni.lodz.pl \\ ORCID: 0000-0003-1544-300X
}

Received 29 April 2020, Accepted 15 March 2021

\begin{abstract}
Research background: Total Quality Management - TQM consists in managing an organization in which the continuous striving for quality based on the Deming Cycle is an important assumption. Even though the 'product', in reference to higher education, is not the same as in reference to industry, higher education can be improved in terms of quality and the manner of conducting classes, and administrative work by applying the TQM methods.

Purpose: The main purpose of the research conducted at the University of Lodz was to identify and compare the determinants affecting the opinion of the students and lecturers on the assessment of the possibilities and effectiveness of introduction of the CQI methods in the Polish higher education.

Research methodology: Multivariate statistical methods - cluster analysis were used for the analysis and cross tabulations.

Results: Students and lecturers of the University of Lodz positively evaluated the CQI methods. The research shows most of the assumptions of the CQI concept can be adapted to the conditions of work at Polish universities; $68.92 \%$ of respondents stated that the CQI methods may be perceived as a concept of improvement of the quality of a university institution; $89.86 \%$ of respondents believe that the CQI methods are appropriate on the concept of the improvement of the quality of given classes/lectures.

Novelty: The value of this paper is a contribution to the debate on needs and improving the quality of education at Polish universities.
\end{abstract}

Keywords: Continuous Quality Improvement, Total Quality Management, quality, higher education, cluster analysis 


\section{Introduction}

Quality is the main factor determining the competitiveness of universities. Only flexible, modern and specialised institutions providing high-quality services are able to gain and maintain a strong market position. The presented factors cause the development of concepts and principles of quality management that may be applicable in the functioning of universities. One of them is Continuous Quality Improvement (CQI) - a method based on the concept of Total Quality Management (TQM).

Continuous Quality Improvement in higher education was initiated by several American pioneers in the 1980s. It is assumed that the CQI philosophy spontaneously appeared in many universities both in the United States of America and the United Kingdom simultaneously (Williams, 1993). This movement was rapidly spreading and in 1990, 78 American universities were examining or trying to implement the CQI concepts (Coate, 1993). In the literature on the subject, the most common topics include quality management models used at universities and a description of problems and successes associated with the implementation of the CQI (see Hau, 1991; Marchese, 1991; Bonser, 1992; Cheffee, Sherr, 1992; Coate, 1993; Nagy et al., 1993; Hansen, 1993; Seymour 1993; Clack, 1993; Assar, 1993; Doherty, 1993; Geddes, 1993; Doherty, 1994; Hogg, Hogg, 1995; Wild, 1995; Hall, 1996; Owlia, Aspinwall, 1997; Ahmed, 2008). Due to the universities' high interest in the CQI methods, many researchers are trying to answer the question: "Can TQM methods be adapted to higher education institutions?" (see Winchip, 1996; Kanji, Malek, Tambi, 1999; Wawak, 2012; Alzafari, Kratzer, 2019; Wawak, 2019). Both the study of S. Winchip (1996) and the paper of K. Alzafari and J. Kratzer (2019) are based on the opinion of quality experts or people publishing articles on the possibilities of adapting the CQI methods in higher education institutions. Expert opinion surveys show that one of the biggest quality challenges in higher education is the unwillingness of researchers to implement high quality. This scepticism has decreased in recent years. Its cause was mainly the fear of bureaucracy and implementation policy, not the value itself (Alzafari, Kratzer, 2019). In Poland T. Wawak has been researching the quality of education for many years. In 20082009, he conducted a pilot questionnaire survey addressed to professors (response rate 14.8\%). The conducted research shows that $71 \%$ of respondents believe that people holding managerial positions at universities should follow the TQM methods. Additionally, 71\% of the surveyed professors believe that a pro-quality management restructuring should be carried out. About $48 \%$ of respondents believe that a self-assessment of the activities of organizational units should be carried out based on the TQM methods and the European model of excellence used 
in the Quality award. Among the surveyed, 41\% of respondents support the implementation at universities of a standardized management system based on ISO 9000 standards and adapted to the conditions of universities (Wawak, 2012). Additionally, it is worth emphasizing the author's conclusions from the study. According to T. Wawak (2012), the opinions of the surveyed professors are varied and partly of them, and therefore some of the respondents are inclined to maintain the current system, despite criticizing it; the surveyed professors are in favour of pro-quality management restructuring, but they do not always see their participation in this process. The author has also carried out other studies on the quality of education, including on the effects of education in economic faculties (Wawak, 2019). There is no opinion in the literature on the subject are of the CQI methods used by students participating in selected CQI elements. Student feedback is very important when implementing the CQI methods, as students play several roles in CQI. As "clients", they use the services offered by universities, as "employees", they do some work and as a "product", they are "sold" to the industry, business and local government after graduation. Therefore, it is so important that students understand the assumptions of the CQI concept and express their opinions and views on the quality of education at universities.

The main purpose of the research conducted at the University of Lodz is to identify and compare the determinants affecting the opinions of the students and lecturers on the assessment of the possibilities and effectiveness of introduction of the Continuous Quality Improvement methods in Polish higher education. The literature review shows that one of the biggest quality challenges in higher education is the reluctance of researchers to implement new methods. Hence, the hypothesis is that students are more open to new education methods than academic lecturers.

The paper is structured as follows. The first section briefly describes the methods and ways of defining the CQI concept. Then, the benefits and barriers encountered in implementing the CQI concept are analysed. In the next step, two respondent surveys are presented - the first one conducted among students of the University of Lodz participating in classes using the CQI methods and another one conducted among lecturers teaching classes in quantitative subjects. Then, the methods and discussion of the results obtained are presented. The last section is the conclusion.

\section{Definition of Continuous Quality Improvement}

TQM consists in the management of an organisation, in which continuous striving for quality by involving all employees and organisational units is an important assumption. 
What is important is the teamwork which requires self-control and awareness of continuous improvement of one's own qualifications. The management initiates, supports and organises actions aimed at enhancing the level of quality. By eliminating defects and preventing the causes of their occurrence, it strives to reduce the number of levels in the organisational structures and work more efficiently. One of the main elements of the concept is to recognise and meet the changing requirements and expectations of the customers by increasing the quality of products and services. The Total Quality Management concept is based on the Deming cycle: Plan-DoCheck-Act (Deming, 1986).

Although the 'product' in relation to higher education is not the same as in relation to the industry, higher education may be improved in terms of quality and the manner of conducting classes as well as supervision over and management of scientific research and administrative work with the use of the TQM philosophy. The words 'management' and 'total' are the typical terms used in the industry, which is why R.V. Hogg and M.C. Hogg (1995) suggest the use of the expression Continuous Quality Improvement (CQI). The term CQI is often used to refer to quality in medicine, healthcare and administrative offices where the 'product' is a human. Continuous Quality Improvement can also be understood as a 'modification' of TQM. By using the concept of TQM, we mean a philosophy functioning throughout the institution, which is very difficult to implement in relation to higher education. Therefore, CQI can be perceived as a concept of quality improvement throughout a university, but also as a concept of improvement of a given subject - a lecture, as a concept of improvement of the way scientific research is carried out or as a concept of improvement of the administrative area. In summary, although the concepts of TQM and CQI could be used interchangeably in literature, it is preferable to use the latter in relation to higher education (Hogg, Hogg, 1995).

\subsection{Benefits and difficulties resulting from the Implementation of Continuous Quality Improvement}

Any organisation implementing a Continuous Quality Improvement programme must define it appropriately for the given specification. Universities need to meet the requirements of the changing environment and respond to the market needs. They play an important role in the process of educating new generations, thus providing a particularly important type of service - knowledge transfer. The following persons may be considered as education clients: a student, a lecturer, a future employer, institutions financing universities and society. Each of these groups will define the quality of educational services in a different way. 
The literature on the subject identifies barriers to Continuous Quality Improvement in higher education. They are also similar to those found in industry. They mainly concern the fear of changes, inadequate resources, or lack of training for staff (Bhat, Rajashekhar, 2009). In addition, there are barriers specific only to education, including difficulty in measuring the learning process, no standards reflecting customer requirements, and difficulty in controlling the learning process due to product diversity (Srikanthan, Darlrymple, 2007). Therefore, the introduction of Continuous Quality Improvement to universities is difficult. Each change takes time and is labour-consuming. This is due to the individuality of each major and faculty. The work and - what is important - the cooperation of both university authorities and all employees should be taken into account in improving the total quality, which is often unattainable. Some people believe that business should not have such a big effect on the education process, which is why they do not want to treat students as 'education clients' (Barrett, 1996). Another important issue is what employees should put more emphasis on - whether it is research and publications or didactic work. Despite the difficulties, a lot of the educational institutions have achieved positive results by implementing CQI. This is demonstrated by the growing number of institutions in the USA and in other developed countries which have implemented the elements of quality management in higher education (Binkley, 1994). In addition, many opponents of the use of TQM in higher education believe that TQM is not a 'recipe for success' for universities, but provides them with the tools necessary to restructure the organization (Ahmed, 2008).

Examples of the successful introduction of the CQI methods in universities include the programmes propagated at Oregon State University (Coate, 1993) or at the Georgia Institute of Technology (Seymour, 1993). The University of Wisconsin-Madison used the CQI methods in the recruitment process (Nagy et al., 1993), while at Harvard College, a quality improvement programme was introduced to improve the library services (Clack, 1993). In addition, one of the good practices for the application of the CQI methods to improve the quality of the classes is the method by Fred Mosteller, a lecturer at Harvard University. In his lectures, he introduced the 'one minute drills', which consist in the fact that students write down (during the last minute of classes) the information on: 1) the main topic of the class, 2) the most difficult topic raised in the class, which the students did not understand, 3) the topic which appeared in class and which the students would like to learn more about (Hogg, Hogg, 1995). According to the author, the most important information is contained in the second point, because the lecturer may return to the problematic topic in the next class. This approach positively affects the attitude of students - on the one hand, it motivates them to work and makes them more focused during a lecture. At Clemson University, a modification of the 'one minute drills' method was introduced by 
informing the students in advance on the need to answer the asked questions. This allowed for achieving additional effects; inter alia, students remember more details and formulate more specific questions (Hogg, Hogg, 1995).

\section{Elements of the methods of Continuous Quality Improvement introduced at the University of Lodz}

In the questionnaire surveys, the CASI (Computer-Assisted Self-administered Interviewing) technique was used, in which a respondent independently completes the electronic version of the questionnaire posted on the website. The questions contained in the questionnaire are separable and the suggested variants exhaust the entire set of possible answers. During the making of the questionnaire, attention was paid to the proper principles of the questionnaire that are presented in the literature (Kaden, 2008). The questions are formulated clearly and briefly, while the proposed forms of the answer are unambiguous. The number of questions is limited to the necessary questions so as not to bore the person filling in the form. The questions are arranged in a logical way, and broken down into 3 parts. The respondents were asked to answer the closed-ended questions, which were provided with a list of prepared, envisaged answers presented to the respondents in the cafeteria.

\subsection{Student opinion study}

The statistical study among the students was divided into 2 stages. It was conducted in the academic year of 2017/2018 at two faculties of the University of Lodz: at the Faculty of Economics and Sociology and the Faculty of Management. The general population consisted of first-year students of the University of Lodz, participating in classes in quantitative subjects: Mathematics (major: Finance and Accounting and Logistics, Faculty of Economics and Sociology) and Mathematics and Statistics in Management (major: Management, Finance and Accounting, Logistics at the Faculty of Management). 19 student groups were drawn independently from all groups available in the USOS system and then, the study discussed below was carried out.

In the first stage of the study, the students participated in classes, during which the concept of Continuous Quality Improvement was introduced to them and various forms of activation were gradually implemented. The methods were selected depending on the major and on the discussed material. The applied activation methods included:

1. Additional consultations. 
2. Revision classes - they took place two/three days before the scheduled date of getting their credits. During the classes, additional tasks in the field of topics for the test were solved. The contents of the tasks were prepared by the students on the basis of the provided literature.

3. Continuous e-mail contact with the lecturer - during the first class, the students were informed that they could send the scan of the answer (complete solution of the task) to the e-mail address for checking. In the case of a correct solution or a minor error, the response was also sent to the e-mail address and if the task was solved incorrectly, the students received information that they should come for consultations. The 'online consultations one day before the test' turned out to be particularly successful - in most of the studied groups, this form of learning was used by 2-7 people, usually on the day preceding the test.

4. 'One minute drills' - modelled on the method used at Harvard University. The purpose of the applied method was to determine which issues were causing problems for students and to motivate the students to participate actively in the classes. It is worth emphasising that after familiarisation of the participants with the 'one minute drills' form, the students prepared answers to the asked questions during the classes - for example, they marked the examples which were difficult for them or they wrote down the issues that interested them. In addition, the lecturers noticed that during the semester the answers to the asked questions were more detailed.

5. Own work in the class - it consisted in solving short (usually simple) examples by the students independently. Own work was used in all classes. The students were instructed to solve the task in about 2-5 minutes and then, the result was checked jointly and the solution was presented on the board.

6. Sending additional materials on the discussed issues.

7. Tests from the discussed topic - after discussion on a given topic, the students took part in the announced tests. The tests did not affect the final grade - they were only a form of checking whether the participant understood the discussed topic well.

In the second stage of the conducted observations, the students participated in the questionnaire survey. The form was the basic source to determine the students' knowledge and opinions on the Continuous Quality Improvement methods. The questionnaire contained detailed information on the factors affecting assessment of the possibility of introducing the CQI philosophy in higher education within the quantitative subjects. Each student participating in the second stage of the study had to meet the following condition - minimum $90 \%$ attendance 
of classes. The forms were available for one month from the date of closing the reports in USOS. The time of the study (after obtaining of the final grade) and the form of the study (online) were used to ensure anonymity as well as to obtain honest opinions from the respondents.

Table 1 presents the rates of responses given by students of the University of Lodz with a breakdown by the type of study, person conducting classes and represented faculty. A total of $24.06 \%$ of responses (109/453) were obtained from students who participated in the second stage of the study.

Table 1. The response rate to the questionnaire survey conducted among students of the University of Lodz

\begin{tabular}{|c|c|c|c|}
\hline \multirow{2}{*}{ Lecturer } & \multirow{2}{*}{ Type of studies } & \multicolumn{2}{|c|}{ Response rate } \\
\cline { 3 - 4 } & & Faculty of Economics and Sociology & Faculty of Management \\
\hline \multirow{2}{*}{$\mathrm{A}$} & full-time & $13 / 67(19.4 \%)$ & $8 / 44(18.2 \%)$ \\
\cline { 2 - 4 } & part-time & $6 / 35(17.1 \%)$ & $7 / 53(13.2 \%)$ \\
\hline \multirow{2}{*}{$\mathrm{B}$} & full-time & $4 / 24(16.7 \%)$ & $28 / 85(32.9 \%)$ \\
\cline { 2 - 4 } & part-time & $14 / 34(41.2 \%)$ & $29 / 111(26.1 \%)$ \\
\hline
\end{tabular}

Source: own elaboration.

\subsection{Lecturer opinion study}

The study was conducted at four faculties of the University of Lodz: at the Faculty of Economics and Sociology, the Faculty of Management, the Faculty of Mathematics and Computer Science and the Faculty of Physics and Applied Informatics. From the faculties mentioned above, the departments teaching quantitative subjects were selected and the questionnaire was sent to the drawn employees together with an attachment describing the CQI methods. The design of the questionnaire and the questions regarding the opinions of the lecturers on the possibility of introducing the CQI methods to the universities were analogous to the questions addressed to the students.

Table 2. The response rate to the questionnaire survey conducted among lecturers of the University of Lodz

\begin{tabular}{|l|c|}
\cline { 2 - 2 } \multicolumn{1}{c|}{} & Response rate \\
\hline Faculty of Economics and Sociology & $23 / 65(35.4 \%)$ \\
\hline Faculty of Physics and Applied Informatics & $6 / 49(12.2 \%)$ \\
\hline Faculty of Mathematics and Computer Science & $5 / 67(7 \%)$ \\
\hline Faculty of Management & $5 / 33(15 \%)$ \\
\hline
\end{tabular}

Source: own elaboration. 
Table 2 presents the rates of responses given by the lecturers of the University of Lodz teaching quantitative subjects with a breakdown by the represented faculty. A total of $18.22 \%$ of responses were obtained (39/214).

\section{Statistical methods}

Cluster analysis is a set of multivariate statistical analysis methods consisting in data segmentation in order to extract homogeneous subjects of the studied population. This method consists in dividing the data set into groups, so as to obtain clusters, in which the elements are similar to each other and at the same time different from the elements from the other groups (Gatnar, Walesiak, 2004).

The cluster analysis methods were used to group the selected variables in order to detect whether there were groups of questions which were similar due to correlated responses to the selected questionnaire questions.

\section{Variables:}

Questions about compliance of the CQI methods with the opinion of the respondents (I fully agree/I rather agree/I have no opinion/I rather disagree/I completely disagree):

P3.1 - It is important to strive for improvement of quality continuously.

P3.2 - It is important to involve all employees in the quality improvement process.

P3.3 - Self-control and awareness of continuous improvement of own qualifications are important.

P3.4 - When using CQI, it is important to operate in a process system (Deming cycle).

P3.5 - CQI may be perceived as a concept of improvement of the quality of a university institution.

P3.6 - CQI may be perceived as a concept of improvement of the quality of given classes/lectures.

P3.7 - CQI may be perceived as a concept of improvement of the quality of scientific research.

P3.8 - CQI may be perceived as a concept of improvement of the administrative area.

P3.9 - Each organisation implementing CQI must define the programme in the manner that is appropriate for the given specification.

P3.10 - I will apply the CQI methods in practice.

P4 - Introduction of CQI to Polish universities will improve the quality of education (yes/I have no opinion/no). 
Questions regarding assessment of the possibility to implement CQI at Polish universities (can be very easily adapted/can be adapted/can be adapted to some extent/I have no opinion/ cannot be adapted):

P5.1 - The employees and students perceive the university as a system.

P5.2 - Education, training and self-development are crucial for the continuous growth and development of university staff and students.

P5.3 - In order to improve quality, everyone (employees and students) at a university must focus on the desired results and not only on meeting the acceptable standards.

P5.4 - The administrative personnel develop long-term plans aimed at continuous improvement of the systems and reduction of bureaucracy.

P5.5 - It is necessary to continuously seek improvements and control the functioning processes.

P7 - Sex (F/M).

P10 - Position (lecturer/student).

Cluster analysis methods are useful, both in grouping 'objects' and 'variables'. The percent disagreement coefficient was used to estimate the distance between clusters. This metric is used for discrete data (Stanisz, 2007). Expression (1) was adopted as a measure of distance:

$$
\mathrm{d}(\mathrm{X}, \mathrm{Y})=\frac{m}{n}
$$

where:

$m$ - the number of pairs such that $x_{i} \neq y_{i}$,

$n-$ the number of all pairs.

The complete linkage method, in which the distance between two clusters is the largest distance of all distances between variables, and the distance between the cluster and the external variable is the largest distance between the elements of the cluster and external variables, was selected as the linkage method (Stanisz, 2007). Figure 1 presents a summary of the obtained results.

An important element of a cluster analysis is the moment of cutting off the dendrogram, which enables determining the number of clusters in the analyzed study. Based on the analysis of the dendrogram and the properties of the received outputs (scree plot), the division of the variables into 4 clusters was made. The structure of the clusters is presented in Table 3. 


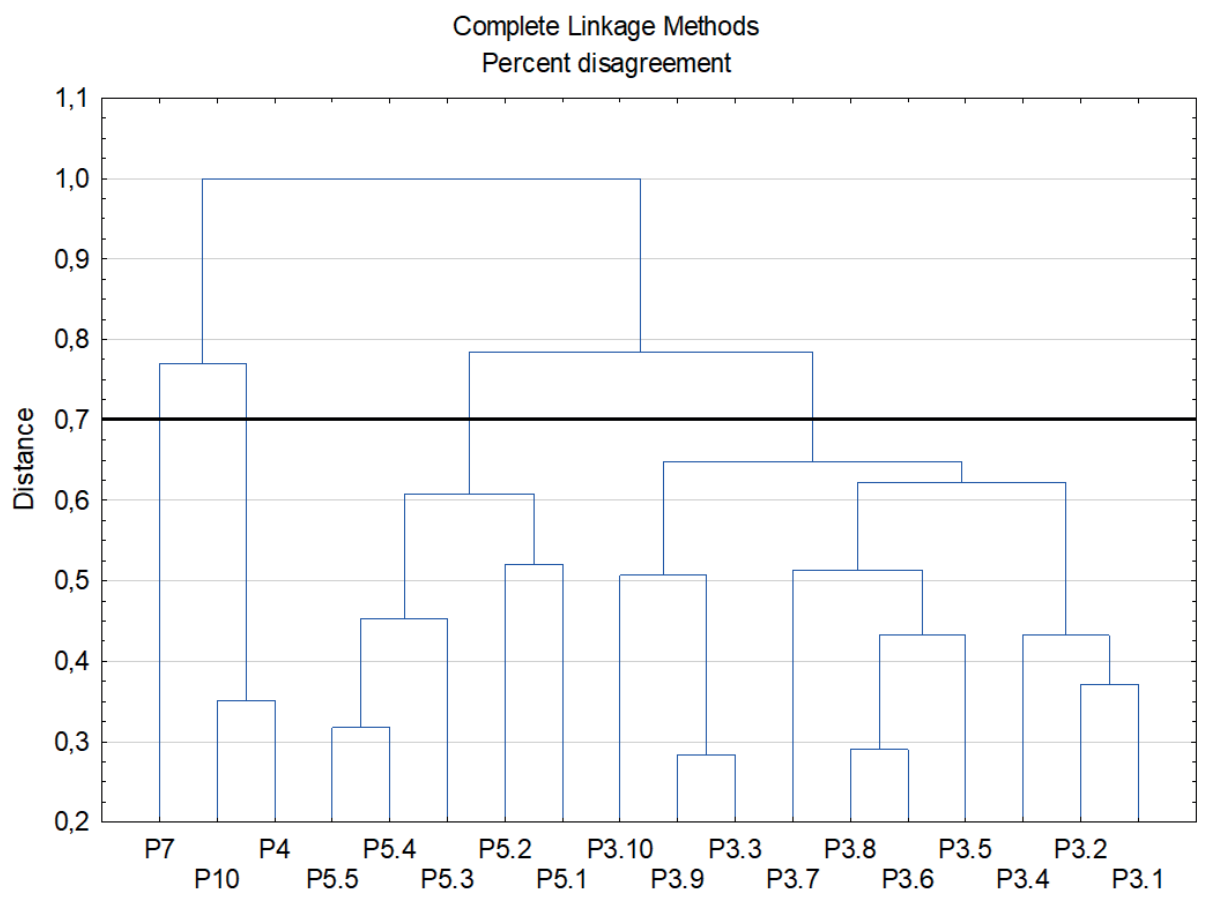

Figure 1. Dendrogram for the questions in the questionnaire

Source: own elaboration.

Table 3. Clusters

\begin{tabular}{|l|l|}
\hline Cluster 1 & $\begin{array}{l}\text { Questions about compliance of the CQI methods with the opinion of the respondents: P3.1, P3.2, } \\
\text { P3.4, P3.5, P3.6, P3.8, P3.7, P3.3, P3.9 }\end{array}$ \\
\hline Cluster 2 & $\begin{array}{l}\text { Questions regarding assessment of the possibility to implement CQI at Polish universities: P5.1, } \\
\text { P5.2, P5.3, P5.4, P5.5 }\end{array}$ \\
\hline Cluster 3 & $\begin{array}{l}\text { P4 - Introduction of CQI to Polish universities will improve the quality of education } \\
\text { P10 - Position (lecturer/student) }\end{array}$ \\
\hline Cluster 4 & $\mathbf{P 7 ~ - ~ S e x ~ ( F / M ) ~}$ \\
\hline
\end{tabular}

Source: own elaboration.

The interpretation of the dendrogram demonstrates that question 4 concerning the effect of Continuous Quality Improvement methods on the quality of education is correlated with the question 10, which means that job position (lecturer/student) does affect the opinion of the respondents regarding the CQI methods. The respondents similarly assess the CQI methods (Table 4), but there is a visible correlation that with the increase of a scientific degree, the belief in the effectiveness of the CQI methods decreases. Among the group of students only 
$1.8 \%$ of the respondents answered "no", while among professors the percentage of negative answers is $10.5 \%$. In addition, we can underline that gender (P7) does not affect the opinion of respondents. Additionally, in cluster 3 we can see the division into groups of questions concerning: the CQI concept (P3.1, P3.2, P3.4); the possibility of implementation at universities (P3.5, P3.6, P3.8, P3.7) and the opinion on the use of CQI in practice (P3.10, P3.9, P3.3).

Table 4. A multi-division table describing simultaneously the distribution of two segmentation variables (P4 and P10)

\begin{tabular}{|c|c|c|c|c|}
\hline & & \multicolumn{3}{|c|}{ Introduction of CQI to Polish universities will improve the quality of education (P4) } \\
\hline & & Yes & I have no opinion & No \\
\hline \multirow{4}{*}{$: \stackrel{0}{\stackrel{0}{0}} \frac{\hat{\sigma}}{0}$} & Student & 84 & 23 & 2 \\
\hline & MSc & 7 & 2 & 0 \\
\hline & Ph.D. & 10 & 7 & 2 \\
\hline & Prof. & 7 & 2 & 2 \\
\hline
\end{tabular}

Source: own elaboration.

\section{Conclusions}

A university starting the implementation of Continuous Quality Improvement must take several basic conditions into account. They are as follows: a change requires time, faculties differ among each other, the change should be well prepared and managed, the people responsible for the change are primarily the university authorities and lecturers. Deming emphasized the role of management in his publications. One of his assumptions about the quality problems is based on the role of a leader. He believed that ' $94 \%$ of all quality problems arise from management's fault' (Deming, 1986). In summary, managers should inspire trust, resolve doubts, take risks and try to eliminate errors as best as possible.

The people who responded to the questionnaire, assessed the Continuous Quality Improvement methods positively. Both students and lecturers recognize that the introduction of the CQI philosophy affects improving the quality of education. In addition, most of the assumptions of the CQI concept can be adapted to the conditions of work at Polish universities. However, it is worth underlining that the response was obtained only from a small group of students (response rate $24.06 \%$ ) and lecturers $(18.22 \%)$.

In addition, it is worth underlining the fact that $68.92 \%$ of respondents declared that they will apply the Continuous Quality Improvement philosophy in practice, and only 6.76\% consider that they 'will not apply' or 'rather will not apply' the CQI methods, while $24.32 \%$ are 
undecided whether putting the philosophy of Continuous Quality Improvement into practice is worth the effort. From among those who chose not to apply the CQI methods, as many as $40 \%$ of respondents believe that these methods can improve the quality of education. Which confirms the opinion of T. Wawak (2012) that the methods of quality improvement are well assessed but are reluctantly implemented in practice by the respondents.

The research shows that $68.92 \%$ of respondents stated that the CQI methods may be perceived as a concept of the improvement of the quality of a university institution. The respondents are more convinced to implement the CQI methods on a concept of improvement of the quality of given classes/lectures (89.86\%). S. Winchip (1996) obtained a similar result. Her research shows that $82 \%$ of the statements in the questionnaire that reflect Deming's philosophy can be adapted to higher education. Additionally, among the respondents, 27.3\% consider the CQI methods as an appropriate method to be implemented in higher education, and $45.5 \%$ believe that this method can be adapted to the working conditions at universities.

The next research direction in the discussed topic will be the assessment of the effectiveness of Continuous Quality Improvement methods. The analyses will compare the final grades obtained among groups of students participating in classes during which the CQI methods were applied with other student groups (of the same fields of study) by using the traditional method. These studies will allow for assessing whether the students participating in the classes which implemented the Continuous Quality Improvement methods were more likely to get very good grades.

\section{References}

Ahmed, J.U. (2008). Quality and TQM at higher education institutions in the UK: Lessons from the University of East London and the Aston University, American International University-Bangladesh. Research and Publications.

Alzafari, K., Kratzer, J. (2019). Challenges of implementing quality in European higher education: an expert perspective. Quality in Higher Education, 25 (3), 261-288. DOI: 10.1080/13538322.2019.1676963.

Assar, K.E. (1993). Case Study Number Two: Phoenix. Quantum Quality at Maricopa. Change: The Magazine of Higher Learning, 25 (3), 22-26. DOI: 10.1080/00091383.1993.9938456. 
Barrett, R. (1996). Quality and the Abolition of Standards: arguments against some American prescriptions for the improvement of higher education. Quality in Higher Education, 2 (3), 201-210. DOI: 10.1080/1353832960020303.

Bhat, K.S., Rajashekhar, J. (2009). An empirical study of barriers to TQM. Implementation in Indian industries. The TQM Magazine, 21, 261-272. DOI: 10.1108/17542730910953031.

Binkley, B. (1994). Total Quality Management and its impact on higher education with emphasis on Academic libraries. Unpublished master's thesis, Tennessee State University.

Bonser, C.F. (1992). Total Quality Education? Public Administration Review, 52 (2), 504-512. DOI: $10.2307 / 976811$.

Chaffee, E.E., Sherr, L.A. (1992). Quality: Transforming Postsecondary Education, ASHE-ERIC Higher Education Report No. 3. Washington, D.C., The George Washington University, School of Education and Human Development.

Clack, M.E. (1993). Organizational development and TQM: The Harvard College Library's experience. Journal of Library Administration, 18 (1-2), 29-43. DOI: 10.1300/ J111v18n01_03.

Coate, E. (1993). The introduction of Total Quality Management at Oregon State University. Higher Education, 25 (3), 303-320.

Deming, W.E. (1986). Out of the Crisis. Cambridge, MA: Massachusetts Institute of Technology Center for Advanced Engineering Study.

Doherty, G.D. (1993). Towards Total Quality Management in higher education: a case study of the University of Wolverhampton. Higher Education, 25 (3), 321-339.

Gatnar, E., Walesiak, M. (2004). Metody statystycznej analizy wielowymiarowej w badaniach marketingowych. Wrocław: Wydawnictwo Akademii Ekonomicznej im. Oskara Langego we Wrocławiu.

Geddes, T. (1993). The Total Quality Initiative at South Bank University. Higher Education, 25 (3), 341-360.

Hall, D. (1996). How useful is the concept of Total Quality Management to the university of the '90s? Journal of Further and Higher Education, 20 (2), 20-32. DOI: 10.1080/0309877960200203.

Hansen, W.L. (1993). Bringing Total Quality Improvement into the college classroom. Higher Education, 25 (3), 259-279.

Hau, I. (1991). Teaching Quality Improvement by Quality Improvement in Teaching. Report No. 59, Center for Quality Productivity Improvement. Madison, WI: University of Wisconsin.

Hogg, R.V., Hogg, M.C. (1995). Continuous Quality Improvement in Higher Education. International Statistical Review, 63, 35-46.

Kaden, R. (2008). Badania marketingowe. Warszawa: Polskie Wydawnictwo Ekonomiczne. 
Kanji, G.K., Malek, A., Tambi, B.A. (1999). Total Quality Management in UK higher education institutions. Total Quality Management, 10 (1), 129-153. DOI:10.1080/0954412998126.

Karaszewski, R. (1999). Total Quality Management. Zarządzanie przez jakość. Wybrane zagadnienia. Toruń: TNOiK Dom Organizatora.

Mącik, R. (2005). Wykorzystanie Internetu w badaniach marketingowych. Lublin: Wydawnictwo Uniwersytetu Marii Curie-Skłodowskiej.

Marchese, T. (1991). TQM Reaches the Academy. AAHE Bulletin, 44, 3-9.

Nagy, J., Cotter, M., Erdman, P., Koch, B., Ramer, S., Roberts, N., Wiley, J. (1993). Case study number three: Madison - how TQM helped change an admissions process. Change: American Association for Higher Education, 25 (3), 36-40. DOI: 10.1080/00091383.1993.9938457.

Owlia, M.S., Aspinwall, E.M. (1997). TQM in Higher Education- a review. International Journal of Quality \& Reliability Management, 14 (5), 527-543. DOI: 10.1108/02656719710170747.

Seymour,D.(1993). Quality on Campus: ThreeInstitutions, ThreeBeginnings. Changes: American Association for Higher Education, 25 (3), 8-18. DOI: 10.1080/00091383.1993.9938454.

Srikanthan, G., Dalrymple, J.F. (2007). A conceptual overview of a holistic model for quality in higher education. International Journal of Educational Management, 21, 173-193. DOI: 10.1108/09513540710738647.

Stanisz, A. (2007). Przystęny kurs statystyki z zastosowaniem STATISTICA PL na przykładach z medycyny. Tom 3 - Analizy wielowymiarowe. Kraków: StatSoft.

Wawak, T. (2012). Jakość zarządzania w szkołach wyższych. Kraków: Wydawnictwo Uniwersytetu Jagiellońskiego.

Wawak, T. (2019). Doskonalenie jakości zarządzania w szkołach wyższych. Kraków: Wydawnictwo Uniwersytetu Jagiellońskiego.

Wild, C. (1995). Continuous improvement of teaching: A case study in a large statistics course. International Statistical Review/Revue Internationale de Statistique, 63, 49-68. DOI: $10.2307 / 1403777$.

Williams, G. (1993). Total Quality Management in higher education: panacea or placebo? Higher Education, 25 (3), 229-237.

Winchip S.M. (1996). Analysis of the Adaptability of W. Edwards Deming's Management Philosophy to Institutions of Higher Education. Quality in Higher Education, 2 (3), 219-236. DOI: $10.1080 / 1353832960020305$. 